(1945).

127) Sam Eagle, etc., Ind. Eng. Ohem., 42, 1, 294 $\sim 9$ (1950).

128)
U. S. 2,530,701 No. 21 (1950). C. A. 46,
2,793 (1952).

129) U. S. $2,640,802$ June 2 (1953). C. A. 47, 11,719 (1953).

\title{
Removal of Organic Sulphur Compounds from Gases
}

\author{
by Wataru Hunasaka, Tetsuo Inaba, and Kazuo Kawano
}

(Kyoto University, Naniwa University)

SYNOPSIS;-A review of the papers and patents on the removal of organic sulphur compounds from gases published in the foreign publications during the period from 1942 to 1954 is given with references taken from the Chem. Abstr.

\section{石炭資源の科学的進路}

一一昭和29年10月20日妥理——

産業振興侏式会社 稳 垣 信 太 郎

要旨: 石炭に科学的処理加工を施し, 熱效率学最高なるものとし, こ杂高低溫連続乾溜に附し,

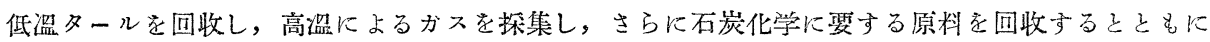

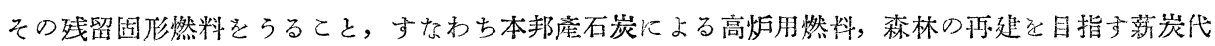
用燃料, 都市の煤洇廃除に要する無烟燃料などを生產するわが石炭資源の科学的高度利用法の磪立 を损唱する。

\section{I 序言}

石炭はわか有する資源中比較的恵まれたるものでは あるが，その絶対量に捺いては決して豊富なるものと はいえない。しかるにこの地下有限資原は採掘された 異質绲成状熊のまま焚焼されており，これが科学的処 理加工による均質化も, 経済的焚焼法の考案も取立て てみるへきもののないのは甚だ遺憾である。熱管理に ついても随分研究されてはいるが，結局それが実際に 応用されている面は全体の消費量からみて誠に僅少な ものであろう。

石炭を熱源として使用せんとするとき，それに科学 的処理加工を施してその均質性を高め, 或はこれに乾 留を施してその熱効率を増進せしめて楚焼すべきは資
䝠愛護の主旨よりみて当然採らるへき!さずのものであ つた。また石嵌の科学的処理加工によつて熱效率を坦 進せしめ，その消費節約を策することは他面化学工業 用原料として貴重なる副生物の回収を図ることとな り，資源乏しさわが国において园に研究され採用技ら るべきであったのである。

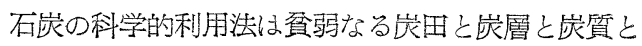
に悩みるもち，常に非能率的なる採炭夫の学務攻勢に 驾和され採炭費引下の術心なき笨状にありて，徒らに 電力による石㞸需要の低下を蒠心, 石油の進出に狼狽 し，さらにまた原子エネルギの利用期に直面するわが 炭咴業界に一種の生気を鼓吹するものであらねはなら ない。 
ここに打いて石炭を過去に打けるがごとくそのまま たぶに燃料として使用するのみでなく，石油抢よび石 炭化学工業に要する原料を回収し，かつその熱効率の 増進を四る科学的处理加工に関する一具体案を揭げて 斯界の批判を乞わんとするものである。

\section{II 石炭微粉研の利点}

石炭の粒度を均斎ならしめれば，その然焼性の増大 することは周知のごとくであり，その粉碎度の進むに 従つてその均質性は顕著となり燃焼は増大寸る。この 瑔理を端的に立証するものは炭础内の岸蝔爆発を誘致 する炭麇の非常に高い燃焼性である。故にこの原理は 微粉炭然燒法に応用され国に多くの目的に実用化され ている。

しかし，微粉燃料は䝪炭ができない，輸送が困難で 华る，自然発灭の怖れがある。これ等の欠点を補うべ く考案された膠状燃料法なども西るが，結局微粉石炭 の非常に活潑な撚焙性を保存しかっその固有の欠点を 克服する方法としては微粉石炭の固体化あるのみであ る。

\section{III 微粉石炭固体化の利点}

1. 普通のピッチ燌炭法 在来の粗粉炭を以てする ※゚ッチ煉炭は同一資料である石炭塊に比し下のごとき 利点がある。

(1). 輸送取扱ともに容易である。2．悪い変化を質 的に与えずに貯炭ができる。3.塊炭に比しピッチ 燤炭は鉄道汽缶などの能率を約 $15 \%$ 増進せしめる。 (4). 一定の火床上においてピッチ烜㞸は生塊岸に比 し約 $25 \%$ 多量に焚燃される。

要するに，在来の粗粉㞸を原料とするピッチ枯宸 の燃焼性は塊炭の燃燒性に優るものである。そして， それは，それら燃料の有つ全く異なつた構造による ものとされる。しかしピッチ痐炭にもまた下のごと き欠点がある。すなわち (イ) 粗粉炭のピッチ枯炭は 完全なる均質性のものでないのみでなく，ピッチの 添加がその構造をさらに複雑なものとする。(可在 来のピッチ稒炭は概して比輘的に脆弱である。

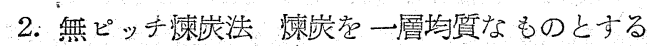
には粘結剤を用いないで，微粉崖を以て䗲炭を造るこ とである。それは粒度の稍や均一である微秎㞸を，そ れ自体に含有する粘結質物によつて結合せしめる方 法，すなわち適当な條件下において一平方时約 $10 \mathrm{t}$ の 圧㩁を施し 成形される徚炭の製造法によるものであ る。かく造られたる煉炭は完全に固体化した微粉炭と 称すべきものであり，他の如何なる方法で処理された 然料より，その構造と組成とにおいて著しき均等性を
有つものである。

またピッチ煉炭はその構造と高き燃焼性とにおいて 最も優秀なる微粉石炭固体化法である。

\section{IV 固体化微粉石炭によるコークス}

乾溜した燃料，特にガスおよび愹鈜炉用コークスな ぞの生成に当って原料に高温を施す場合に構成される 熔融し難い㟶素の黒鉛的被膜が燃焼しにくい性質のた め, その燃焼現象は生の然料と同様に複雑であり,そ の燃燒性を決定する因子の数は一般に認識されている ものよりも多いのである。すなわち, 1. 粘結, 非粘 結性の原料の性格。2. 加圧, 温度, 時間なぞの乾溜 條件。3. 原料の混合およびその一部加熱加工なとに よる予储処理。4. 表面積の大小拉よび気孔構造の本 質。 5. 細胞構造の 連続性と 細胞の大きさなどであ る。

要するに，固体化したる微粉石炭は以上の要因に最 もよく適合したる性状を具備するものであり，てれは 高, 中, 低いずれの温度で乾溜を施しても, 燃烓性の 大きい，硬度の高い，見脚比重の大きいコークス在生 成することができるのである。允してそのコークスは 高度の気孔率, 一単位質量内の著大なる表面積, 著し き細胞の構造, 著しき細胞壁における気孔, 著しき連 続性細胞の分布, 極微細胞の大きな此率などの特微を 具備する比類なき理想的新燃料である。

コークスの然堯性の難易は一般に考光られているよ うに乾溜の温度またはコークス中に抟留する揮発分の 多寡のみによるものではなく，その難易を決めるもの は酸化ガスに接触するコークスの表面積とその本質と によるものでありここの原理を雄充に物棓る絶好の燃 料は木炭である。そして木炭に等しく自由然焼をする ものは固体化したる微粉石岸を以てするコークスであ る。

註 低温乾溜による半成コークスの然焼性はとの残留 する揮発分に因るものではなく，その構造に起因す るものとされる。これを概説すれば，多くの乾燥さ れたボイラーコールおよび純無烟炭は半成コークス と略々同率の揮発分を有つものであるが, その火床 面上におちける然焼性は遥かに低いのである。また半 成コークス研究すると, それは, 此較的厚い細胞 壁をもつ海綿のごとき塊を構成している。そして， その燃焼過程に抢いて，この細胞壁中に保有される 揮発分は，放出されるが熔融は起らない，何故なれ ば，その愹融性成分は低温乾溜によってすでに変質 されているからである。そして半成コークス中の揮 発性ブスの放出によって，細胞壁を貫く微細な孔を 
生じる。その結果, 酸化性ガンに露出される表面積 が著しく増加し,よつてその然燒性を大ならしめる ものであるとされる。

\section{$\mathrm{V}$ 高低溫連続乾溜を可能ならしめる 固体化したる微粉石炭}

1. それは低, 中, 高, いずれの温度にて畭溜する も可なるものであり, いずれの温度にて乾溜な施して も，その高き燃煃性を保存する。

2. それは炉内において膨脹, 粘着, または破壞な ぞの盧なきよう必要に応し適宜予備処理を経たる硬質 緻密のものであり, 乾溜行程の連続操作に適したるも のである。

3. それは, その乾溜行程の連続操作によつて 低温 タールを回収し，高温によるガスを採集し，しかる後 固形燃料它生蓙する。

4. 固体化したる微粉石炭の乾溜は上記三種の主要 生成物を生産し, 石炭の粉碎, 成形, 乾溜などに要卞 る費用をとれら主要生産物に適宜割当て採算的にも有 利ならしめる。

\section{VI 乾溜用固体化微粉石炭とその原料石炭}

本法式による新コークスの用途,たとえは人造木炭, 都市無烟燃料，熔鉱炉用然料等それら各用途によつて 多少の差異はあるとしても, 穴の原料としては重㟶, 褐炭, 瀝青炭等の総てが利用され得るのであり, ある ものは天然のまま,またあるものは予備处理を必要と するであろう。しかし，その原料とする石炭の種類， 性状などに関する選択は略ほ自由にできる。従つて乾 溜用石炭の範囲は著しく拡大する。

\section{VII 固体化微㸮石炭乾溜法の採算的検討}

1. 石炭を乾溜すれば, ガス, 固体残渣抢よびター ルの三種の生成物起得るが, 高温乾溜の場合はガスと コークス, 低温乾溜の場合はコーライトと低温タール とが主要生成物であり，いずれも二種に局限されるの であるが，本法式によれば同一乾溜装置内で低温一高 温乾溜が連続的に行われるため, 低温タールとガスと 新コークスの三種の主要生成物を得ることができる。 これは頗る大きな経済的利点であらねばならない。

2. 高温乾溜の場合も, 低温乾溜の場合も, その乾 溜費は各二種の主要生産物が負担するのであるが，本 法式による場合, その乾溜費は三主要生産物によつて 分担される。これは上述の主要生産物の一種増加とと もに本法の経済的利点である。

3. 本法式によれば，石炭中の揮発分の大半をがス として採集するにも拘わらず，物理的表面燃焼の作用 はえの然焼性を完完全に保持世しめる。これもまた本法
式の一利点とみるべきである。

4. 本法式による新ニークスのもつ高度燃燅性は燃 料の消費量を低減し, 主要生産物を一種增加し, 副産 物として石炭化学工業に要する貴重なる原料を回収し 得るため, 石炭の粉砕，成形などに要する一見穴費の ごときものを補填して余りあり, 本法式の採算的利点. と見做すごとができよう。

5. ガスコークスもコーライトも非常に脆弱である ため, その取扱または運搬中に粉砕される率が頗る高 く，二者ともにその燃料価值は低下するのであるが， 本法式による新コークスは硬質, 緻密, 容易に破砹せ ず，輸送打よび取扱中にも粉末化の盧れはない。従つ て，その価值を損うこともない。

6. 各炭础における水選微粉は本法による新コーク スの原料となり，炭破における新利用源として検討せ らるべきであろう。

\section{VIII 固体化微粉石炭を以てする 新コークスの用途}

1. 木炭代用然料 本法式による新コークスは無烟 無臭, コークスともコーライトとも豆煉炭とも全くそ の性状を異にし, かっそれらの有つ欠点を悉く除去し た, 硬質緻室, 着火と火持のよい, 立消えせ好, 木崖 に酷似した完全無欠な人造木炭である。それは, 在来 の代用然料之異なり, 特種の器具も, 装置も, 燃焼法 も必要とせず, 木炭同様に火消壼を用い, 或は水消し て再三使用し得る経済的家庭燃料である。

2. 愹鈜炬用燃料、本法式による新コークスの特長 を次に述へる。

(1). 二酸化炭素の高率な生成を裔し, 燃料一封度当り の熱量の増加となる。

(2). 鉱石の直接還元を留し, 炭菜消費量の節約となる。

(3). ガスとともに搬出される顕熱に因る熱の損失を減。 少せしめる。

(4). 輻射熱に因る熱の損失究減少せしめる。

(5). 石灰石の減少, 釷滓の減少, 樊量損失の減少なと に起因方る燃料消費量の減少と節約とを濟す。

(6). 本法式による新ニークスの緻密度は熔鉣炉の容積 を少からず縮少せしめる。これは固定資本の縮減と なり，生産費の削減ともなりまた既設の炉を操業す る場合は現在より著しく出銑量を増加せしめるであ ろう。

要するに輸入強粘結㟶を必要とせぬ本法式による 新コークスは, その密度において純無烟炭に近く， そのドラム古よび落下強度は92〜98とされ，その燃 焼性は木炭のごとき反応力旺盛なものである。 


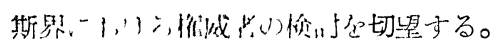

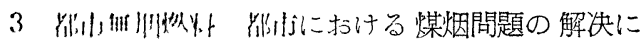

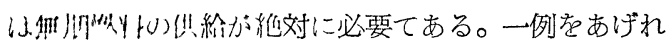

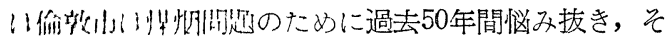

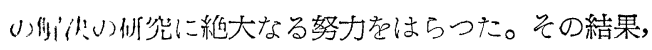
4III 细悛料によらさる解决策なしとし，英政府は過きる

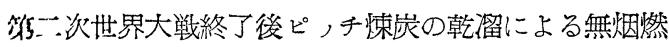
料ファテサィトの製造を直営し，一力年30万tの供給 そなしつつあるが, その生産才増強を企図しつつある。 わが国においても煤烟問題は㫀く取上げられつつあ り, 都市住民の健康, 経済, 或は都市美観のため悦ぶ ヘきであるが，如何にせん，その目的達成のために必 要なる無烟然料の供給法がない現状である。低品位炭

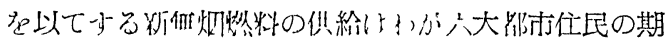

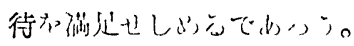

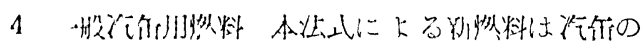

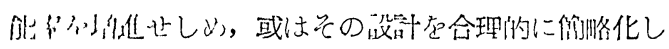
䍀る理淪的可诣性か多分にあるとされる。左椂の溉念 に関し少しく要点を述へて識者の批判を气うこととす る。

汽缶炉内における石炭の然焼は周知のことく次の三 段階を経る。すなわち, 揮発分の放出, 揮発分の然焼, そして揮発分の放出されたあとに残された固形炭素質 分の燃焼である。そして汽缶の炉床上に抢ける揮発分 の放出と然焼とは, 汽全内の能率に由々しき不利を䟭 す因子を誘致するものてあるが，それを概説すれは次 のことくである。

(1). 汽缶の炉床上における白熱した燃料塊と, 缶体と の間に乾溜生成かスか介在する場合に発生寸る輻射 熱の伝導を多分に妨げる。

(2).それらのガス，その燃焼により生成される物質

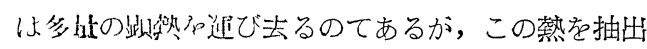

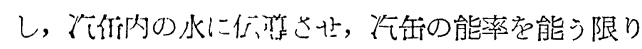

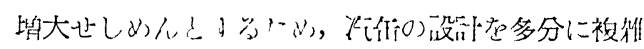
化するものてい文。

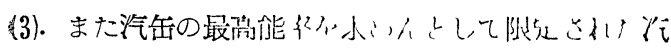

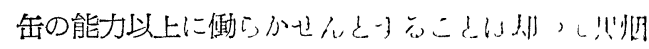
の排出と能率の低下と祒くものている。

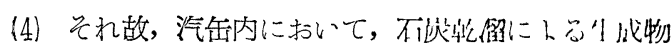
を有効に処理せんかため, 複雑な機㧴ストーカ一, 節約機, 過熱装置なとの設備を必要と与をものでは るが，これに反し，本法による新然料は，そのち」 容易に燃焼するものであるため，汽缶に上記のよう な繌雉な設備を必要とせざのみでなく，次のことき 大心なる利益を提供する。

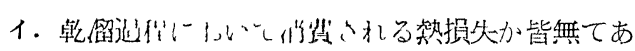
る。

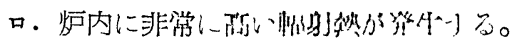

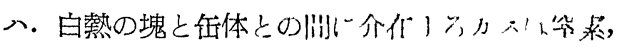

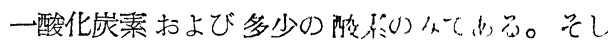

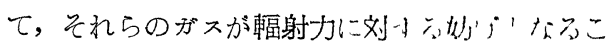
とは非常に少ない。

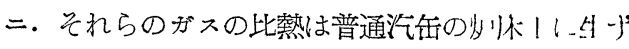
る不燃の炭質分の燃焼による生成物, 靲缩に上る 混合ガスなとの比熱よりは小さい。それ故，档订 な節約機, 過熱装置などの施設の多くは不要とな る。

(5).これらの因子中, 最も重要なるものは, 輻射熱で ある。しかしその重要性は一般に認識されておらな いのであるが，研究すれはその使用効果を増大せし

める可能性は著大であることがわかる。

（6）さらに住目に価する一因子がある。それは本法式 による新燃料の構造についてみれはわかることく， それのもつ表而䅡と, 気孔率とによつて, 自由燃焼 をする燃料か炬床上に生成され，より非常に大量の 一酸化炭素加発生し, 白熱の表面にお㇒て然焼し, 直接の輻射によつて，伝導する輻射の割合を著しく 増進させることてある。

要するに,この種然料の汽缶楚としての使用は汽缶 に次のことき革命的改良を盾すものであるとされる。 すなわち，イ、既設汽午の能力を少からず増加する。 口. 汽缶の効率を向上せしめる。八. 汽缶の設計を単 純化する。二. 汽缶の建設費を低减せしめる。亦水 夫なとの人件費を節約する。

\section{IX 固体化微枌石㞸を以てするカスス生産事業}

本法式に上れは，然え難く砕け易いがスコークスに

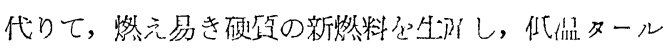

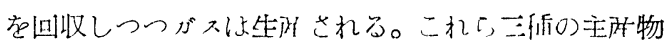

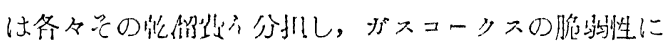

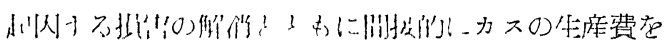

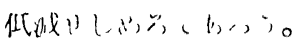

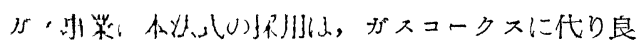

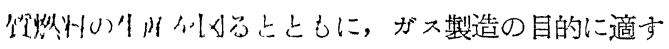

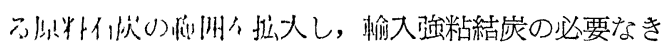

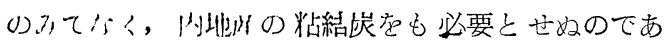
\%。

\section{X 結}

ねが地下有限答源である石炭は埋蔵量豊富ならず， 嵌留上つしからず，炭層厚からず，しかも過去におけ る滥掘と非科学的燃焼法とによつて，その延命と消費 
節約との悲願は䟿蕗され，今やその採炭コス下は外国 のそれを上迴り, わが全産業の基礎に重大なる悪影響 を与えつつあるは周知のごとくである。

この業界の衰䫋を狙つて虎視诺㙆たる外国石油関係 一連の動きがあり, 国策線上の電力開発の急速なる進 捗あり，さらにまた原子ェネルギの実用期は刻々に迫 りつつあるとき, わが石崖鈗業界の採るべき途は然料 石炭より化学工業原料石炭への転換を図るべきではな かろうか。この着想は独りわが国のみでなくForward to Coal in the New Era の声高らかに石㟶科学の研 究に懸命の努力党続けつつある英国の炭業界および石 炭からすでに200種類以上の化学製品を生産しつつ西 る米国の一会社の事業にみて，科学的研究による石炭 の貴重化を企図することは特にわが炭業界の実情に鑑 みればその必要さらに一層痛切なるものであらねばな らない。

毎年約一億石の過伐に荒廃しつつあるわが森林の再 建はまずその過伐を上廻る燃材の伐採在必要とする薪 炭の使用を石炭系のガス, 人造石油, 人造木炭を以て おき換えるべき重大なる便命，強粘結孷と鉄鉱石とを もたないかが製鉄工業は最悪の立地條件下に置かれ， 技術的には欧米のそれに追従しつつありて, その経営 の容易ならざるものがある。この難問題を解決する唯 一の途は本邦蓙弱粘結宸を以てする新然料の考案, 都 吊煤烟問題の解決に要する経済的無烟燃料の生産およ び将来わが産業をリードせんとする石炭化学工業の発 展なぞ, 総て石炭科学の研鑚にまって達成さるべきも のである。筆者は本交におらて石炭の処理加工とその 影響に関する一例を述べて石炭科学研究の重要性に対
する認識を諸賢とともに新たならしめんとするもので ある。

文献

1）栗原鑑司，燃料協会誌，第 31 号。

2）栗原鑑司著, 石炭乾䬶工業 昭15.

3）稻垣信太郎著，人造石油事業の再検討，昭和15年。

4）英国に於りる刊行物

4-a. Report of the Fuel Research Board for the years, 2, 1920 1921,

"Low Temperature Carbonization"

by the Department of the Scientific and Industrial Research. Published 1922.

4-b. "The Reactivity of Coke as a Factor in the Fuel Economy of the Blast Furnace"

By E. R. Sutcliffe and E. C. Evans

Delivered before the Annual meeting of Iron and Steel Institute. May. 10 11, 11071923

4-c. "A Study of the Destructive Distillation of Coal" by E. V. Evans. Chief Chemist and Product Manager, South Metropolitan Gas Co., Delivered before the Royal Society of Arts. Feb. 44 45. 1924,

4-d. "The Influence of Structure on the Combustibility and other Properties of Solid Fuels" by E. R. Sutcliffe and E. C. Evans. The Journal of the Society of Chemical Industry, 41, 196 208T (1922)

\title{
Scientific Forward of Coal Resources
}

\author{
by Shintaro Inagaki
}

(Sangyo Shinko Co.)

SYNOPSIS : In order to increase heat efficiency of coal as much as possible, the author applied some scientific treatments with it. Coal is carbonized through some vertical continuous retort, thus to obtain tar and gas at low and high temperatures respectively. Further it is aimed to recover materials for coal chemical industry and consequent residual solid fuels such as combustible coke for blast-furnace use, charcoal substitute for reconstructing our forests, smokeless fuel for preventing smoke nuisances etc. The author describes the establishment of the highest scientific utilization of our coal resources. 